\title{
A study on the effect of earnings management on restatement and the changes on information content of earnings following restatements: Evidence from Tehran Stock Exchange
}

\author{
Saeid Ali Ahmadi ${ }^{a^{*}}$, Afsaneh Soroushyar ${ }^{a}$ and Hosein Naseri ${ }^{\mathrm{b}}$
}

${ }^{a}$ Department of Accounting, Khorasgan (Isfahan) Branch, Islamic Azad University, Isfahan, Iran ${ }^{b}$ Department of Accounting, Payam Noor University, Kerman, Bam, Iran

\section{CHRON I C L E}

\section{Article history:}

Received August 25, 2013

Received in revised format

19 September 2013

Accepted 23 October 2013

Available online

November 82013

Keywords:

Earnings Management

Earnings Restatement

Discretionary Accruals

Information Content of Earnings

Tehran Stock Exchange

\section{A B S T R A C T}

The current impressive increase in the number of the restatements, encourage many researchers to find the causes of restatements including earnings management. Moreover, restatements increase the uncertainties of investors about earnings and decrease its information content. Therefore, the purpose of this research is to investigate the relationship between earnings management and earnings restatements. In addition, this paper examines the information content of earnings and cash flow following restatements period. For this purpose, we use one logistic regression and three multiple regressions with OLS method over the period 2001-2011. The results indicate that there was no significant relationship between discretionary accruals and earnings restatement, but magnitude of the discretionary accruals as the proxy of earnings management was significant and positively associated with the earnings restatement. Moreover, the earnings had more information content than cash flow before and after the earnings restatement. The overall result suggests that the one reason for earnings restatement is to make earnings management in an emerging market.

\section{Introduction}

Financial statements are the primary purposes of financial reporting. According to statement of financial accounting concepts No. 8, the aim of financial reporting is to provide financial information about the reporting entity, which is useful for existing and potential investors, lenders, and other creditors in making appropriate decisions about providing resources to the entity (FASB, 2010). Applying accrual system is necessary to present the relevant and continuous information about financial operation. Managers always have the opportunity of manipulating in earnings by changing the timing expense and revenue recognition. Therefore, accruals happen in aggressive actions of management to recognition, record and report the financial events, and this is an instrument for

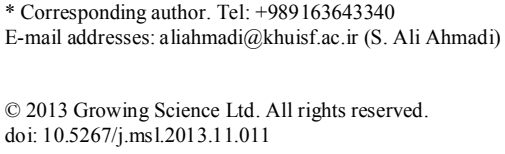


financial statements manipulation (Sloan, 1996). This objection is associated with non-discretionary accruals. Furthermore, because cash flows component of earnings are more objective, making any change on financial statements is difficult and in terms of earnings restatement, change the earnings probably happens on accrual components. Accrual is one of the earnings management measures, which indicates the motivations behind earnings restatement is earnings management.

Pervious literature shows that earnings explain the market value more than cash flows does. For instance, Dechow (1994) showed that accruals could improve the ability of earnings to measure the company performance. Although, over the time cash flows suffer by matching problem more than earnings, but earnings is dominance. This notion indicates that participants in market emphasize on earnings, therefore the firms' motivation for earnings management increases. It seems that firms apply the financial statements restatement as an instrument for earnings management. Desai et al. (2006) reported expert investors consider the high total accruals as the index of poor earnings quality. They motioned, by positive relations of short positions and accruals, accounting information is useful to forecast restatement. Earnings before restatement is more timeliness and relevant than cash flows are and restatement includes signals for investors. Restatement by correction unintentional errors is the primary concerns of most investors about recurrence and about manipulation of financial statements. Therefore, restatement of financial statements leads to increase the investors' unreliability, risk and information asymmetry (Palmrose \& Scholz, 2004) and probably after restatement, emphasis of investors is on cash flows rather than earnings increase.

The general purpose of this research is to examine the relationships between earnings restatement and earnings management and compare the reaction of capital market before and after restatement. Accordingly, this study addresses three research questions. First, do the earnings restatement relate to earnings management? Second, after restatement, does the emphasis of capital market on earnings decrease? Third, after restatement, does the emphasis of capital market on cash flows increase?

We contribute to the earnings management and information content literature on earnings restatement in an emerging market. We evaluate the role of earnings management in restatement an emerging market. Considering increase restatement in capital market, one of reasons for earnings restatement can be earnings management, which needs to be more explored in developing countries. Furthermore, we explore the market reaction to before and after earnings restatement to show the status of information quality in emerged market.

The test results show that the positive association between magnitudes of the discretionary accruals with earnings restatement is statistically significant. Furthermore, the test results suggest that the earnings have more information content than cash flow before and after the earnings restatement.

The rest of the paper proceeds as follows. Section 2 contains the economic environment in Iran. Section 3 introduces relevant previous studies. Section 4 describes hypothesis development. Section 5 presents sample selection. Section 6 contains research design. Section 7 presents the empirical results of this study. Section 8 concludes our paper with the summary and concluding remarks.

\section{Economic Environment in Iran}

Emergence of a developing financial market due to privatization and economic growth and development have increased the need for accountants and auditors in Iran, and have caused the accountancy-related issues to be more seriously addressed. The legal system is considered as an important factor influencing on accounting system (Nobes, 1983), and particularly in Iran, the legal system is probably the most influential determinant of accounting discipline.

\subsection{Tehran Stock Exchange (TSE)}

Tehran Stock Exchange (TSE) was founded in 1967. In the first year, only six companies were in the TSE list. In 1989 along with the revitalization of the private sector and privatization of the state- 
owned enterprises, a new economic program began to develop the promotion of private sector activities. This coincided with the time that the first five-year national development plan in the country was at the initial stage of designing. In fact, the TSE has grown as one of the most important executive mechanism for promoting the national economy. This aimed at the environment facilitating contribution of the private sector in productive programs actively, transferring some state duties to the private sector and mobilizing private savings into investment programs. Since then the stock exchange market has grown continuously till today. In recent years, the TSE has evolved into an exciting and growing marketplace for many investors. Now there are more than 460 firms in the TSE investors' trade-in securities hall. The new Capital Market Law was passed in November 2005, forty years since the establishment of the TSE. Under the new law, TSE would be restructured and incorporated in the private investment. (Pourheydari \& Ali Ahmadi, 2008)

\subsection{Audit Organization (AO) and Iranian Association of Certified Public Accountants}

Audit Organization, established in 1987, is a governmental institution which takes the responsibility of accounting and auditing in Iran. The organization is a part of Ministry of Economic Affairs and Finance, and includes Accounting and Auditing Standards Setting Committees, which are legal authorities to set accounting and auditing procedures. Audit Organization is the only regulatory body in charge of setting accounting and auditing standards in Iran. Audit Organization has the responsibility for auditing governmental business units and most other organizations with public ownership. In fact, Audit Organization is by far the biggest auditor firm in Iran (Farajzade \& Makarem, 2011).

Invoking a bill ratified by parliament, Iranian Association of Certified Public Accountants (IACPA) was established in 2001. Based upon the bill, government is permitted to apply professional services of certified public accountants. Only IACPA members are permitted to establish audit firms. Currently, auditing of governmental firms is mostly carried out by AO and other entities are audited by other audit companies. By the end of 2011, more than 100 audit firms along with AO were adopted by TSE as reliable auditor (Farajzade \& Makarem, 2011).

\section{Literature Review}

In this section, several related studies are reviewed on earnings management in restatement and the changes in information content of earnings following restatements. The study of Kinney and McDaniel (1989) is one of the first studies in this area where they showed that firms that corrected previously reported quarterly earnings were smaller, less profitable, had higher debt, and were slower growing relative to comparable firms in their industry. DeFond and Jiambalvo (1991) investigated firms that had overstated and subsequently corrected their annual earnings and found that such firms had diffuse ownership and lower growth in earnings and were less likely to have audit committees. In recent studies, some people examined the role of earnings management and information content on the restatement of financial statements as follow. Ettredge et al. (2013) investigated the impact of financial restatements on managers' subsequent earnings forecasts. The results suggested that compared with control firms, restatement firms showed a declined propensity to issue quarterly earnings forecasts on restatements. Hence, they reported that managers of restatement firms could show risk-averting forecasting behavior after restatements.

Herly (2012) compared the earnings quality in US firms required to restate their financial statements with the quality of a matched control group. He examined whether the earnings quality differed in ten years before (last) restatement event for two groups. The results indicated that the restating firms could improve the quality of their financial statements. Eng et al. (2012) investigated earnings informativeness after financial restatements. They used the earnings response coefficient (ERC) as the proxy of the information content earnings. The results suggested that financial restatement could 
lead to decrease in investor confidence to reported earnings. Plumlee and yohan (2010) examined causal influences attributable to restatements. They provided the experiment evidence to address two questions. (1) To what causes do companies attribute restatements? (2) To what characteristics of the accounting standards do companies attribute restatements? The results showed that firms most often attributed restatements to the internal errors. They also reported that, for those restatements attributed to some characteristic of the accounting standards, the main factor was the ambiguous in applying the accounting standards. Jones et al. (2008) responded to the question whether models of discretionary accruals could detect actual cases of fraudulent and restated earnings. The goal was to make an assessment on the ability of the popular discretionary accruals models (i.e. ten models) to detect extreme cases of earnings management. They reported that only the accrual estimation errors estimated from cross-sectional models of working capital changes on cash flows and the McNichols model had predictive power for both fraud and non-fraudulent restatements of earnings.

Wilson (2008) addressed whether the decrease in the information content of earnings was long-lasting by measuring the earnings response coefficient (ERC) over a multiple-year period surrounding restatements. He assessed the information content of earnings by using a standard earning-return framework. He reported that the decline in the information content of earnings following restatements was temporary. In addition, the results indicated that the decrease on information content was more pervasive for firms that corrected errors of revenue recognition and for firms that experienced a severely negative stock price decline at the restatement announcement. Shough and Tao (2007) examined the association of returns to earnings and cash flows before and after financial restatements. The results suggested that after financial statement was restated, the relationship between returns and cash flows was increased and the relationship between returns and earnings was decreased. The overall result supported the idea that restatement could lead to ambiguity and then investors rely less on earnings and more on cash flows in firm valuation after a restatement. The results of research by $\mathrm{Wu}$ (2003) indicated that the earnings response coefficient (ERC) decline dramatically following restatement, which could be considered as a loss of confidence among investors. Hribar and Jenkins (2004) suggested that accounting restatements could influence on expected future earnings and cost of capital and it could result to both decreases in expected future earnings and increases in the firm's cost of equity capital.

\section{Hypothesis Development}

Considering General Accepted Accounting Principles (GAAP), restatement includes the two main categories. First, restatement is as a result of changes in accounting principles and second, is as a result of accounting errors (Callen et al., 2003). The subsequent category contains admission by management to non-GAAP financial reporting, and is probably the reasons where management consciously and intentionally take in earnings manipulation (Richardson et al., 2002). Thus, restatement may happen for different reasons and earnings management is one of the most important items. Managers encounter massive pressure to meet or beat expectations established by various groups (for example, analysts, and directors). Hence, they can use earnings management to response the expectations. Earnings management can make with the use of accounting discretion, intentional accounting misstatement, or use of real transactions to alter the numbers reported in the financial statements to effect outcomes that depend on reported accounting numbers. Thus, we expect that earnings management impact on financial restatement in market capital, significantly. The one and two hypotheses of research presented as follow:

$\mathrm{H}_{1}$ : The relationship of earnings management (discretionary accruals) with earnings restatement is significant.

$\mathrm{H}_{2}$ : The relationship of the magnitude of earnings management (discretionary accruals) with earnings restatement is significant. 
Efficient capital markets reward high-quality financial reporting, which facilitates the efficient raising and allocation of corporate capital and thus creates potential advantages for investors (Wang \& $\mathrm{Wu}$, 2011). The high-quality financial reporting can be created by the useful information. The usefulness of accounting information influences on users' decisions. Furthermore, the primary objective of reported information for users is to help them make appropriate decision making. When the reported information becomes useful and maintains high quality, it helps investors make correct decisions. Companies that restate their financial information may signal to the stock market about the lack of sufficient transparency, completeness, and reliability of financial reported, thereby misleading users to make incorrect decisions (Flanagan et al., 2008). When firms release their financial information on the capital market, people may wish to make investment decisions. Restatements are explicating signals to the investors who previously filed financial statements contain errors. Thus, we expect that the restatement influences on the information content. Therefore, we consider the following hypotheses,

$\mathrm{H}_{3}$ : After restatement, the relationship between earnings and market value is decline.

$\mathrm{H}_{4}$ : After restatement, the relationship between cash flow and market value is increase.

\section{Sample Selection}

Our sample covers companies listed on Tehran Stock Exchange (TSE) over the period 2001-2011. The sample selection criteria are as follows,

1. The end of fiscal year was March 2001;

2. The end of fiscal year did not change over the period 2001-2011;

3. Their basic operations were not investment, insurance and banking;

4. Book value of assets were not negative;

5. Data was available during the period of study.

Given to above criteria, final sample included 111 firms.

\section{Research Methodology}

In order to test of hypothesis presented in $\mathrm{H}_{1}-\mathrm{H}_{2}$, we used the logistic regression and multiple regression models. These models are applied by Jones et al (2008). In these models the depended variables are the restatement of and the earnings different of financial statements. Also, independent variables include the assets total, return of assets, leverage, type of auditor and discretionary accruals. Equations are illustrated as follows,

$$
\begin{aligned}
& \text { RESTATE }_{i t}=\alpha_{0}+\alpha_{1} A T_{i t}+\alpha_{2} \text { ROA }_{i t}+\alpha_{3} \text { LEVERAGE }_{i t}+\alpha_{4} A O_{i t}+\alpha_{5} D A C C_{i t}+\varepsilon_{i t}, \\
& \text { DEFRESTATE }_{i t}=\alpha_{0}+x_{1} A T_{i t}+\alpha_{2} R_{i t}+\alpha_{3} \text { LEVERAGE }_{i t}+\alpha_{4} A O_{i t}+\alpha_{5} D A C C_{i t}+\varepsilon_{i t},
\end{aligned}
$$

where RESTATE is a dummy variable, which is equal to 1 for financial restatement firms and 0 , otherwise. In addition, DEFRESTATE is the difference between actual reported earnings and the restated earnings (i.e. before and after rested earnings) scaled by $A T_{t-1}$. $A T$ is the total assets scaled by $A T_{t-1}, L E V E R A G E$ is the ratio of total debt to total assets scaled by $A T_{t-1}, A O$ is a dummy variable, which is equal to 1 for firms audited by audit organization (AO) and 0 , otherwise and $D A C C$ is discretionary accruals measured by McNichols model (2002) given in Eq. (3). We estimate crosssection model by following a model presented by McNicbols (2002). The discretionary accruals are used as the proxy of earnings management.

$\Delta \mathrm{WC}_{\mathrm{it}}=\alpha_{0}+\alpha_{1} \mathrm{CFO}_{\mathrm{i},-1-1}+\alpha_{2} \mathrm{CFO}_{\mathrm{i}, \mathrm{t}}+\alpha_{3} \mathrm{CFO}_{\mathrm{i}, t+1}+\alpha_{4} \Delta \mathrm{REV}_{\mathrm{it}}+\alpha_{5} \mathrm{PPE}_{\mathrm{it}}+\varepsilon_{\mathrm{it}}$, 
where $\Delta \mathrm{WC}$ is the change in working capital from year $t-1$ to year $t$, CFO is the operating cash flow, $\triangle \mathrm{REV}$ is the change in firm sales and PPE is the gross property, plant and equipment. The multiple regression models used to examine of hypothesis presented in $\mathrm{H}_{3}-\mathrm{H}_{4}$. These models are applied by Shough et al. (2007). In this model, pendent variable is market value and independent variables are book value, operation cash flow and earnings. To test the hypotheses the following models are used.

$$
\begin{aligned}
& M V_{i t}=\alpha_{0}+\alpha_{1} N I_{i t} \times \operatorname{RESTATE}_{i t}+\alpha_{2} B V_{i t}+\varepsilon_{i t}, \\
& M V_{i t}=\alpha_{0}+\alpha_{1} C F O_{i t} \times R E S T A T E_{i t}+\alpha_{2} B V_{i t}+\varepsilon_{i t},
\end{aligned}
$$

where $M V$ is the market value, $N I$ is the earnings, CFO is the operation cash flows, RESTATE is a dummy variable, which is equal to 1 for financial restatement firms and 0 , otherwise and $B V$ is book value.

\section{Results}

Descriptive statistics of variables are demonstrated in Table $1 \mathrm{a}$ and Table 1b. Descriptive statistics of market value, earnings and operating cash flow are based on million Rials. Results of descriptive statistics indicate the standard deviation of earnings is less than operation cash flows. The 65 percent of sample firms, on average, is earnings restatement, which is high percent. In addition, during the period of research, the private auditor audited $69 \%$ of sample firms.

Table 1a

Descriptive Statistics of Variables

\begin{tabular}{lccccccc}
\hline Statistics & AT & ROA & Leverage & DACC & Market value & Earnings & Operating Cash flow \\
\hline Mean & 1.198 & 0.131 & 0.295 & 0.012 & 925,085 & 179,471 & 180,725 \\
Median & 1.194 & 0.102 & 0.269 & 0.002 & 232,860 & 37,951 & 31,492 \\
Maximum & 4.713 & 0.668 & 1.353 & 1.018 & $23,116,800$ & $7,698,801$ & $10,513,626$ \\
Minimum & 0.252 & -0.43 & 0 & -0.947 & 7,875 & $-681,926$ & $-2,293,788$ \\
Std. Deviation & 0.282 & 0.125 & 0.202 & 0.179 & $2,332,443$ & 664,483 & 789,260 \\
\hline
\end{tabular}

Table 1b

Descriptive Statistics of Variables

\begin{tabular}{lcccccccccc}
\hline Year & 2002 & 2003 & 2004 & 2005 & 2006 & 2007 & 2008 & 2009 & 2010 & Av \\
\hline Earnings Restatement (\%) & 71 & 69 & 64 & 67 & 67 & 68 & 58 & 60 & 64 & 65 \\
Private Auditor (\%) & 48 & 58 & 69 & 71 & 73 & 74 & 76 & 78 & 76 & 69 \\
\hline
\end{tabular}

The first model tests the relationship of earnings restatement and earnings management. The results of this model estimation are presented in Table 2. The coefficient of the discretionary accruals is 0.285 but no significant. Therefore, unlike the notion, there isn't any significant relation between the restatement and earnings management.

Table 2

\begin{tabular}{|c|c|c|c|c|}
\hline \multicolumn{4}{|c|}{ RESTATE $_{i t}=\alpha_{0}+\alpha_{1} A T_{i t}+\alpha_{2} R O A_{i t}+\alpha_{3} L E V E R A G E_{i t}+\alpha_{4} A O_{i t}+\alpha_{5} D A C C_{i t}+\varepsilon_{i}$} & \multirow[b]{2}{*}{$\begin{array}{c}\chi^{2}-\text { statistics } \\
p \text {-value }\end{array}$} \\
\hline Variables & Coefficients & $t$-statistics & p-value & \\
\hline$A T_{i t}$ & -0.036 & -0.09 & 0.931 & \multirow{5}{*}{$\begin{array}{c}12.08 \\
(0.033)\end{array}$} \\
\hline$R O A_{i t}$ & -1.476 & -1.21 & 0.228 & \\
\hline$L E V E R A G E_{i t}$ & -0.947 & -1.20 & 0.228 & \\
\hline$A O_{i t}$ & 0.937 & 2.64 & 0.008 & \\
\hline$D A C C_{i t}$ & -0.285 & -0.55 & 0.582 & \\
\hline
\end{tabular}

Logit regression of earnings restatement on discretionary accruals 
Model 2 examines the relationship between earnings restatement and difference of earnings before and after restatement. In other words, the relationship of earnings restatement and the magnitude of earnings restatement are tested. The results of the model estimation are presented in Table 3 . The result indicates that $\alpha_{5}$ is equal to 0.007 and statistically significant. Therefore, if the restated earnings are highly different from prior earnings, probably earnings restatement is performed with the aim of earnings management.

Table 3

Pooled regression of earnings restatement magnitude on discretionary accruals

\begin{tabular}{|c|c|c|c|c|c|}
\hline \multicolumn{6}{|c|}{ DEFRESTATE $=\alpha_{0}+x_{1} A T_{i t}+\alpha_{2} R O A_{i t}+\alpha_{3} L E V E R A G G_{i t}+\alpha_{4} A O_{i t}+\alpha_{5} D A C C_{i t}+\varepsilon_{i t}$} \\
\hline Variables & Coefficients & t-statistics & $p$-value & $\begin{array}{c}\text { F-statistics } \\
(p-\text {-value })\end{array}$ & Durbin-Watson \\
\hline$A T_{i t}$ & 0.003 & 9.085 & 0.000 & \multirow{5}{*}{$\begin{array}{l}154.489 \\
(0.000)\end{array}$} & \multirow{5}{*}{2.149} \\
\hline$R O A_{i t}$ & -0.024 & -24.557 & 0.000 & & \\
\hline$L_{E V E R A G E_{i t}}$ & -0.004 & -6.765 & 0.000 & & \\
\hline$A O_{i t}$ & -0.0002 & -1.164 & 0.244 & & \\
\hline$D A C C_{i t}$ & 0.007 & 12.914 & 0.000 & & \\
\hline
\end{tabular}

Adjusted R-squared $\quad 0.007$

The regression models (4) and (5) are applied to examine the third and fourth hypotheses. Based on these hypotheses, after earnings restatement, the relationship between market value and earnings has been decreased and, on the contrary, the relation between market value and operating cash flow has been increased. The results obtained from estimation of models (4) and (5) are respectively presented in Table 4 and Table 5.

Table 4

Earnings and cash flow models for the firms do not restate earnings

\begin{tabular}{|c|c|c|c|c|c|}
\hline$M V_{i t}=\alpha_{0}+\alpha_{1} N I_{i t}+\alpha_{2} B V_{i t}+\varepsilon_{i t}$ & \multicolumn{4}{|c|}{$M V_{i t}=\alpha_{0}+\alpha_{1} C F O_{i t}+\alpha_{2} B V_{i t}+\varepsilon_{i t}$} & \multirow[b]{2}{*}{$\mathrm{p}$-value } \\
\hline & $\alpha_{1}$ & $\alpha_{2}$ & $\mathrm{R}^{2}$ & $F$-statistics & \\
\hline Coefficients in earnings model: & 2.017 & 0.476 & \multirow{3}{*}{0.54} & \multirow{3}{*}{59488.36} & \multirow{3}{*}{0.000} \\
\hline t-statistics & 68.051 & 329.65 & & & \\
\hline p-value & 0.000 & 0.000 & & & \\
\hline Coefficients in cash flow model: & 1.255 & 0.477 & \multirow{3}{*}{0.536} & \multirow{3}{*}{57131.83} & \multirow{3}{*}{0.000} \\
\hline t-statistics & 48.941 & 326.838 & & & \\
\hline p-value & 0.000 & 0.000 & & & \\
\hline
\end{tabular}

Table 5

Earnings and cash flow models for the firms restate earnings

\begin{tabular}{|c|c|c|c|c|c|}
\hline$M V_{i t}=\alpha_{0}+\alpha_{1} C F O_{i t}+\alpha_{2} B V_{i t}+\varepsilon_{i t}$ & $M V$ & $\varepsilon_{0}+\alpha_{1} \Lambda$ & ${ }_{2} B V_{i t}$ & & \\
\hline & $\alpha_{1}$ & $\alpha_{2}$ & $\mathrm{R}^{2}$ & F-statistics & $\mathrm{p}$-value \\
\hline Coefficients in earnings model: & 3.076 & 0.006 & \multirow{3}{*}{0.74} & \multirow{3}{*}{145956.3} & \multirow{3}{*}{0.000} \\
\hline$t$-statistics & 294.392 & 3.519 & & & \\
\hline p-value & 0.000 & 0.0004 & & & \\
\hline Coefficients in cash flow model: & 1.266 & 0.263 & \multirow{3}{*}{0.58} & \multirow{3}{*}{70777.2} & \multirow{3}{*}{0.000} \\
\hline$t$-statistics & 123.859 & 116.39 & & & \\
\hline p-value & 0.000 & 0.000 & & & \\
\hline
\end{tabular}

The Coefficients of earnings and cash flows for the firms are 2.017 and 1.255 and significant and do not restate earnings. Adjusted R-squared in earnings model is equal to 0.54 and higher than the adjusted R-squared in cash flow model (0.536). Although this difference is low, but according to 
Dechow (1994), this is resulted in the ability of accruals (as the other component of earnings versus) for improvement of firm value explanation. The coefficients of earnings and cash flows for the firms restate earnings are 3.076 and 1.266 and significant. Adjusted R-squared in earnings model is 0.74 and higher than the adjusted R-squared in cash flow model (0.58). Therefore, after restatement, the ability of earnings to explain the firm value is on higher than cash flow.

\section{Conclusion and remarks}

The increase trend in earnings restatements over the last decade has increased concerns among market regulators and analysts and investors' skepticism regarding the quality of financial reporting of companies announcing accounting restatements. The International Accounting Standards Board (IASB) and the Financial Accounting Standards Board (FASB) emphasis the importance of "reliability" as a primary qualitative characteristic required to make accounting information useful to users making economic judgments and decisions. Reliability can interpret to a quality of financial statement that makes it a verifiable, faithful representation of transactions and events that have occurred within a company. Thus, earnings restatement may indicate the prior information presently is not correct. Hence, when financial statements are restated, it showed that previous financial presentations were not reliable. In this regard, the purpose of present paper was to study the relation between earnings management and earnings restatement. In addition, the information content of earnings and cash flows before and after testament has been compared.

In our survey, 65 percent of sample firms, on average, reported earnings restatement, which is a high percentage. In addition, during the period of research, the private auditor audited $69 \%$ of sample firms. The results indicated that earnings management was not associated with earning restatement, but the relation of earnings management and difference of earrings before and after restatement was positive and significant. The result is consistent with findings of Jones et al. (2008). We cannot be sure about the intention behind the earnings restatement was earnings management, but the higher difference of earnings before and after restatement showed that the aim of restatement was earnings management. Furthermore, the other results of this study are that before restatement, the ability of earnings to explain the market value was higher than cash flow. However, on the contrary to the theoretical expectation, after restatement, the ability of earnings to explain the firm value was higher than cash flow. In other words, even after restatement, earnings played essential role for investors' decision making and determined the value of companies. It seems that investors' functional fixation and thus, the result was inconsistent with the notion that restatement creates uncertainty for investors in market capital. This result is inconsistent with the results reported earlier by Shough and Tao (2007), Wilson (2008) and Eng et al. (2012).

Considering the increase trend on the restatement and the role of earnings management in restatement, we recommend that market regulators and Iranian Association of Certified Public Accountants (IACPA) to exactly monitor and to control on restatement. In addition, companies are required to disclose the reasons for the restatement in order to disclose the economic consequences of restatement to the users and improve the quality of restatement disclosures.

\section{References}

Aier, J., Comprix, J., Gunlock, M., \& Lee, D. (2005). The Financial Expertise of CFOs and Accounting Restatements. Accounting Horizons. 19(3), 123-135.

Badertscher, B., Hribar, S., \& Jenkins, N. (2011). Informed Trading and the Market Reaction to Accounting Restatements. The Accounting Review. 86(5), 1519-1547.

Callen, J.L., Livant, J., \& Segal, D.(2003). Accounting restatements: are they always bad news for investors?. Working paper, University of Toronto and New York University. 
Dechow, P. M. (1994). Accounting earnings and cash flows as measures of firm performance. The role of accounting accruals. Journal of Accounting and Economics, 18, 3-42.

Desai, H., Krishnamurthy, C. S., \& Venkataraman, K. (2006). Do short sellers target firms with poor earnings quality?: evidence from earnings restatements. Review of Accounting Studies, 11(1), 7190.

DeFond, M., \& Jiambalvo, J. (1991). Incidence and Circumstances of Accounting Errors. The Accounting Review, 66, 643-655.

Efendi, J., Kinney, M., \& Swanson, E. (2004). Can short sellers predict accounting restatements?. Working paper, California Polytechnic State University, San Luis Obispo, CA.

Eng, L. L., Rao, R. P., \& Saudagaran, S. (2012). Earnings informativeness after financial statement restatements. International Journal of Revenue Management, 6(3), 221-245.

Ettredge, M., Huang, Y., \& Zhang, W. (2013). Restatement disclosures and management earnings forecasts. Accounting Horizons, 27(2), 347-369.

FASB. (2010). Conceptual Framework for Financial Reporting. Statement of Financial Accounting Concepts, 1, Stamford, CT: FASB.

Farajzade, H., \& Makarem, N. (2011). The effect of size and type of auditor on audit quality. International Research Journal of Finance and Economics, 80, 121-137.

Flanagan, D. J., Muse, L. A., \& O'Shaughnessy, K.C. (2008).An overview of accounting restatement activity in the United States. International Journal of Commerce and Management. 18(4), 363381.

Jones, K., Krishnan, G., \& Meleudrez, K. (2008). Do models of discretionary accruals detect actual cases of fraudulent and restated earnings? An Empirical Analysis. Contemporary Accounting Research, 25(2), 499-531.

Kinney Jr., W.R., \& McDaniel, L. (1989). Characteristics of firms correcting previously reported quarterly earnings. Journal of Accounting and Economics, 11, 71-93.

Hribar, P., \& Jenkins, N.T. (2004). The effect of accounting restatements on earnings revisions and estimated cost of capital. Review of Accounting Studies, 9, 337-356.

Herly, M. (2012). Earnings quality in restating firms: experimental evidence. Master Thesis in Finance and International Business Aarhus University.

McNichols, M. E. (2002). Discussion of The quality of accruals and earnings: The role of accrual estimation errors. The Accounting Review, 77, 61-69.

Moore, E. A., \& Pfeiffer. R. J. (2004). The effects of financial statement restatements on firms' financial reporting strategies. www.ssrn.com.

Nobes, C.W. (1983). A judgmental international classification of financial reporting practices, Journal of Business Finance and Accounting, 10(1), 1-19.

Palmrose, V., \& Scholz, S. (2004). The circumstances and legal consequences of non-GAAP reporting: Evidence from restatements. Contemporary Accounting Research, 21(1), 139-180.

Plumlee, M., \& Yohn, T. (2010). An analysis of the underlying causes attributed to restatements. Accounting Horizons, 24(1), 41-64.

Pourheydari, O., \& Ali Ahmadi, S. (2008). Accruals and cash flows in equity valuation: Iranian case. Middle Eastern Finance and Economics, 2, 5-15.

Richardson, S., Tuna, I., \& Wu, M. (2002). Predicting earnings management: The case of earnings restatements. Working paper, University of Pennsylvania and Hong Kong University of Science and Technology.

Shough, A., \& Tao, E. (2007). The relationship of returns to earnings and cash flows before and after restatement. www.ssrn.com.

Sloan, R., \& Richard. G. (1996). Do stock prices fully reflect information in accruals and cash flows about future earnings. The Accounting Review, 71, 289-315.

Wilson. W. (2008). The information content of earnings following restatements. The Accounting Review. 83(2), 519-548.

Wu, M. (2003). Earnings restatements: A capital market perspective. Working Paper. New York University. 
Wang, X., \& Wu, M. (2011). The quality of financial reporting in China: An examination from an accounting restatement perspective. China Journal of Accounting Research, 4, 167-196.

Zhen Li, O., \& Zhang. Y. (2006). Financial restatement announcements and insider trading. www.ssrn.com. 